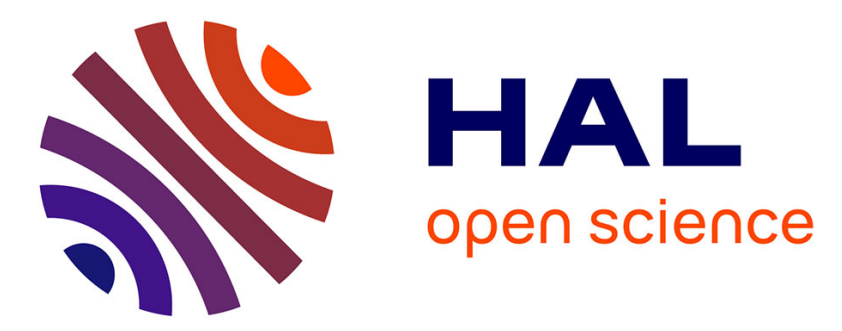

\title{
Bioactive Seed Layer for Surface-Confined Self-Assembly of Peptides
}

\author{
Cécile Vigier-Carriere, Tony Garnier, Déborah Wagner, Philippe Lavalle, \\ Morgane Rabineau, Joseph Hemmerlé, Pierre Schaaf, Bernard Senger, Fouzia \\ Boulmedais, Loïc Jierry
}

\section{To cite this version:}

Cécile Vigier-Carriere, Tony Garnier, Déborah Wagner, Philippe Lavalle, Morgane Rabineau, et al.. Bioactive Seed Layer for Surface-Confined Self-Assembly of Peptides. Angewandte Chemie International Edition, 2015, 54 (35), pp.10198-10201. 10.1002/anie.201504761 . hal-01409676

\section{HAL Id: hal-01409676 https://hal.science/hal-01409676}

Submitted on 27 Jan 2020

HAL is a multi-disciplinary open access archive for the deposit and dissemination of scientific research documents, whether they are published or not. The documents may come from teaching and research institutions in France or abroad, or from public or private research centers.
L'archive ouverte pluridisciplinaire $\mathbf{H A L}$, est destinée au dépôt et à la diffusion de documents scientifiques de niveau recherche, publiés ou non, émanant des établissements d'enseignement et de recherche français ou étrangers, des laboratoires publics ou privés. 


\title{
Bioactive Seed layer for Surface Confined Self-Assembly of Peptides**
}

\author{
Cécile Vigier-Carrière, Tony Garnier, Déborah Wagner, Philippe Lavalle, Morgane Rabineau, Joseph \\ Hemmerlé, Bernard Senger, Pierre Schaaf*, Fouzia Boulmedais* and Loïc Jierry
}

\begin{abstract}
The design and control of molecular systems that selfassemble spontaneously and exclusively at or near an interface represents a real scientific challenge. We present here a new concept, an active seed-layer that allows overcoming this challenge. It is based on enzyme-assisted self-assembly. An enzyme, alkaline phosphatase, which transforms an original peptide, $\mathrm{Fmoc}-\mathrm{FFY}\left(\mathrm{PO}_{4}{ }^{2}\right.$ ), into an efficient gelation agent by dephosphorylation, is embedded in a polyelectrolyte multilayer and constitutes the "reaction motor". A seed-layer composed of a polyelectrolyte covalently modified by anchoring hydrogelator peptides constitutes the top of the multilayer. This layer plays the role of nucleation site for the Fmoc-FFY peptide self-assembly. When such a film is brought in contact with a Fmoc$\mathrm{FFY}\left(\mathrm{PO}_{4}{ }^{2-}\right)$ solution, a nanofiber network starts to form almost instantaneously which extents up to several micrometers into the solution after several hours. We demonstrate that the active seedlayer allows convenient control over the self-assembly kinetics and the geometric features of the fiber network simply by changing its peptide density.
\end{abstract}

Self-assembly has become over the last years one of the most active fields in chemistry and material science with more than 120000 references responding to this key word on Web of Science. When restricting the research to the two topics "surface-confined" and "self-assembly" only slightly more than 100 references remain and most of them address independently the two topics. This clearly demonstrates that the design of molecular systems that self-assemble spontaneously and exclusively at or near an interface represents a real scientific challenge. The most valuable approach developed so far to address this problem is to use non-self-assembling entities (molecules or macromolecules) that undergo a chemical change at the interface and thereby acquire a self-assembling propensity. Confining this chemical change at the interface can be achieved by using chemical reactions or physical processes catalyzed by molecular entities called morphogens (such as protons or metallic cations) that diffuse from the surface towards the solution, creating a concentration gradient, a strategy used

[*] C. Vigier-Carrière, Dr T. Garnier, D. Wagner, Prof. P. Schaaf*, Dr F. Boulmedais*, Dr L. Jierry

Institut Charles Sadron, CNRS-UPR 22

23 rue du Loess, 67034 Strasbourg Cedex, France

E-mail: fouzia.boulmedais@ics-cnrs.unistra.fr; schaaf@unistra.fr Dr P. Lavalle, Dr M. Rabineau, Dr J. Hemmerlé, Dr B. Senger, Prof. P. Schaaf

INSERM Unité 1121 "Biomaterials and Bioengineering" 11 rue Humann, 67085 Strasbourg Cedex, France

[**] C.V.-C. was supported by a fellowship from CNRS and "Région Alsace". T.G. and D.W. acknowledge ANR ("FORCELL", ANR-12 BSVE5-0021) for financial support. We gratefully acknowledge icFRC (Project Labex CSC-PSC-13), USIAS and IUF for financial support.

Supporting information for this article is given via a link at the end of the document.((Please delete this text if not appropriate)) by Nature. ${ }^{[1]}$ In synthetic approaches, the generation of these morphogens requires the continuous application of an external stimulus such as light ${ }^{[2]}$ or electrochemistry ${ }^{[3]}$ to maintain the selfassembly process alive.

In 2004, a new way to initiate gel formation in the bulk was introduced and called enzyme-assisted self-assembly (EA-SA) ${ }^{[4]}$ The authors used alkaline phosphatase (ALP) to dephosphorylate a short Fmoc-protected peptide which becomes instantaneously an hydrogelator in the reaction medium due to the decrease of its water solubility. EA-SA was intensively developed by several groups who extended the concept to many more enzyme/peptide systems, getting success in fields such as inhibition of cancer cell lines, ${ }^{[5]}$ intracellular imaging and intratumoral chemotherapy ${ }^{[6]}$ or biocatalysis. ${ }^{[7]}$ In 2009, the group of Ulijn grafted enzymes onto a substrate and observed the formation of localized peptide-based fibers originating from microscopic globules that were identified as enzyme clusters. ${ }^{[8]}$

Herein, we present the design of a new generation of surface localized EA-SA allowing the control of the hydrogel formation exclusively at and from a surface. The ability of the surface to initiate and to tune its own coating is based on the use of polyelectrolyte multilayer architectures that offer the possibility to design highly organized and enzymatically active nanometer size films. ${ }^{[9]}$ Polyelectrolyte multilayers are organized structures obtained by the alternate deposition of polyanions and polycations onto a substrate. ${ }^{[10]}$ They constitute an ideal tool to functionalize surfaces. ${ }^{[11]}$ The general architecture we propose is represented in Figure 1a. It is composed of three main film components: (1) a precursor multilayer deposited on the substrate, rendering the whole process substrate independent; (2) an enzyme layer deposited onto the precursor layer and (3) a seed-layer composed of polyelectrolytes modified by anchoring hydrogelator peptides. When precursor peptides, i.e. peptides that do not interact with each other in solution, reach the multilayer, an enzymatic reaction occurs at the film/solution interface, ${ }^{[12]}$ generating effective hydrogelator peptides at the film/solution interface. An increase of the concentration of hydrogelator peptides occurs near the film/solution interface and induces their spontaneous self-assembly initiated from, what can be called, a bioactive seed-layer. Gel formation thus starts exclusively from the surface. In this work, we demonstrate the validity of this approach and the control of the formation of a gel on the surface through the presence of the active seed-layer.

Inspired by hydrogelator/enzyme systems introduced by Yang and Ulijn, ${ }^{[13]}$ we designed an original peptide FmocFFY $\left(\mathrm{PO}_{4}{ }^{2-}\right)$ with a phosphorylated phenol group of the tyrosine at $\mathrm{C}$-terminal position as model to validate our concept (Figure 1b). Alkaline phosphatase (ALP, $150 \mathrm{kDa}$ ) was used as catalytically active enzyme inducing the dephosphorylation of Fmoc- $F F Y\left(\mathrm{PO}_{4}{ }^{2-}\right)$ leading to the local production of the 
hydrogelator Fmoc-FFY.
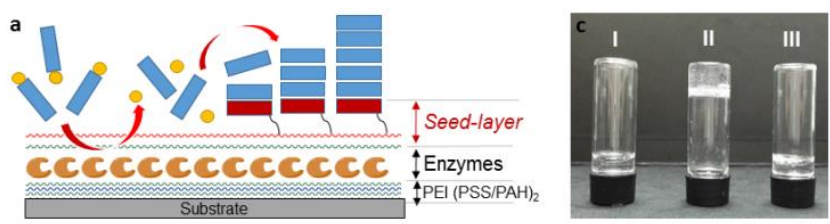

b
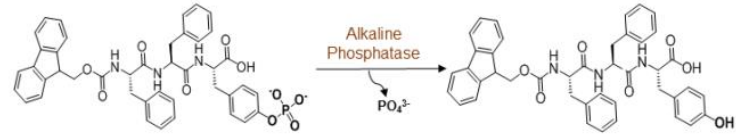

Fmoc-FFY

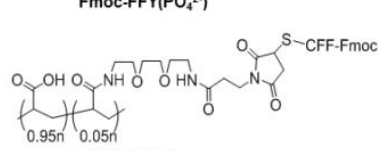

PAA-CFF-Fmoc

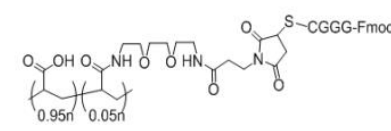

PAA-CGGG-Fmoc

Figure 1. (a) Schematic representation of the surface localized EA-SA concept; (b) Chemical structures of all peptides and modified polyelectrolytes involved in this work $(\mathrm{C}=$ Cysteine, $\mathrm{F}=$ Phenylalanine, $\mathrm{G}=$ Glycine, $\mathrm{Y}=$ Tyrosine, Fmoc = Fluorenylmethyloxycarbonyl group); (c) Gelation tests realized in vials with different solutions: (I) $0.90 \mathrm{mM} \mathrm{Fmoc-FFY}\left(\mathrm{PO}_{4}{ }^{2-}\right)$ and ALP (1 U.mL $\left.{ }^{-1}\right)$; (II) $\left.0.60 \mathrm{mM} \mathrm{Fmoc-FFY(PO}{ }_{4}{ }^{2-}\right)$, PAA-CFF-Fmoc $(0.30 \mathrm{mM}$ of "CFF-Fmoc") and ALP (1 U.mL $\left.{ }^{-1}\right)$; (III) $0.90 \mathrm{mM} \mathrm{Fmoc-FFY}\left(\mathrm{PO}_{4}{ }^{2-}\right)$, PAA and ALP $\left(1\right.$ U. $\left.\mathrm{mL}^{-1}\right)$. The vials were turned upside down after $15 \mathrm{~min}$.

The seed-layer is composed of poly(acrylic acid) chains (PAA, $M_{n}=100 \mathrm{kDa}$ ) modified with the hydrogelator Fmoc-FFC through a short spacer (Figure 1b). The presence of the cysteine at C-terminal position allows clicking the peptide Fmoc-FFC through the thiol-ene reaction onto a maleimide-modified PAA. The grafting ratio of PAA-CFF-Fmoc is around $5 \%$ according to ${ }^{1} \mathrm{H}$ NMR spectroscopy. Syntheses and characterization of all compounds used in this work are reported in the Supporting Information (SI, Part 1). We first verified in solution (I) that gelation can be induced by dephosphorylation of Fmoc$\mathrm{FFY}\left(\mathrm{PO}_{4}{ }^{2-}\right)$ in the presence of ALP, (ii) that Fmoc-FFY, generated in situ, is an efficient hydrogelator and (iii) that PAACFF-Fmoc interacts with the peptide Fmoc-FFY, promoting gel formation. All the experiments were performed at $25^{\circ} \mathrm{C}$ and at pH 9.5 using a borax buffer solution (SI, Part 2).

Next we wanted to validate the concept of seed-layer acting as a "nucleating agent" and favoring the self-assembly of a gel on the surface. For this purpose we built a $\mathrm{PEI}-(\mathrm{PSS} / \mathrm{PAH})_{2^{-}}$ PAA-CFF-Fmoc film (PEI: poly(ethylene imine); PSS: poly(styrene sulfonate); $\mathrm{PAH}$ : poly(allylamine hydrochloride)) and brought it in contact with a mixture solution containing Fmoc- $\mathrm{FFY}\left(\mathrm{PO}_{4}{ }^{2-}\right)$ at $0.90 \mathrm{mM}$ and ALP at $0.33 \mathrm{mg}^{-1} \mathrm{~mL}^{-1}$ (or 1 U. $\left.\mathrm{mL}^{-1}\right)$. The process taking place at the interface was followed in situ by Quartz Crystal Microbalance (QCM) by monitoring the evolution of the opposite of the fundamental resonance frequency shift $-\Delta f_{1}$ and the corresponding dissipation $D_{1}$. Whereas no gel is observed in solution in these conditions (Figure 1c), a strong increase of $-\Delta f_{1}$ is observed at the injection of (Fmoc- $\left.\mathrm{FFY}\left(\mathrm{PO}_{4}{ }^{2-}\right), \mathrm{ALP}\right)$ mixture up to a value of $1200 \mathrm{~Hz}$ after $8 \mathrm{~min}$ of buildup (Figure S1). In the same time, an important increase of the dissipation $D_{1}$ is measured, up to a high value of $900 \times 10^{-6}$. This indicates the formation of a thick viscoelastic gel on top of the multilayer. As a control experiment, the PAA-CFF-Fmoc seed-layer was replaced by a modified PAA grafted with $5 \%$ of Fmoc-GGGC, a sequence recently described as an ideal non-gelating peptide (we also verified this result in solution (Figure S1). ${ }^{[14]}$ When the Fmoc-FFY $\left(\mathrm{PO}_{4}{ }^{2-}\right)$ and ALP mixture was brought in contact with a PAA-CGGG-Fmoc ended multilayer, only a small increase of the QCM signals were observed $\left(-\Delta f_{1}\right.$ increases by $20 \mathrm{~Hz}$ and $D_{1}$ by $180 \times 10^{-6}$, Figure S1). When a PAA-CFF-Fmoc ended multilayer film was brought in contact with ALP in the absence of Fmoc-FFY $\left(\mathrm{PO}_{4}{ }^{2-}\right)$, almost no variations of $-\Delta f_{1}$ and $D_{1}$ were observed by QCM (Figure S2). These results prove that the layer of PAA-CFF-Fmoc deposited on the multilayer serves indeed as an effective seed-layer.

Let us now go one step further and see if one can create a bioactive seed-layer by incorporating the "reaction motor", i.e. $A L P$, in the multilayer instead of having it in the solution.

a

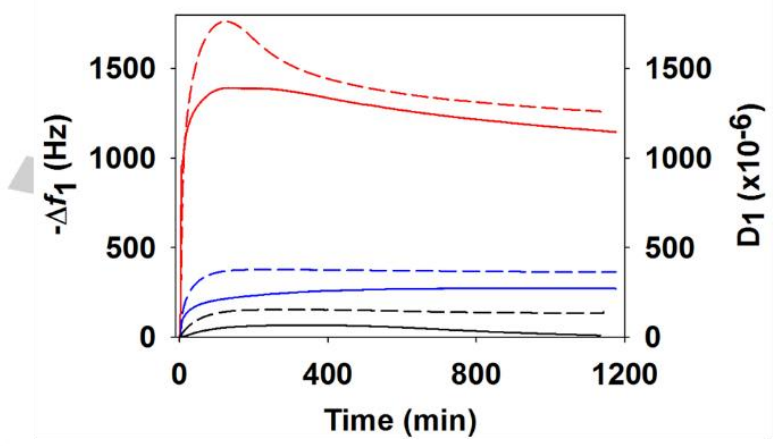

b

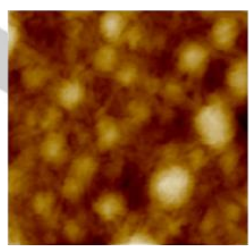

$5 \mathrm{~min}$

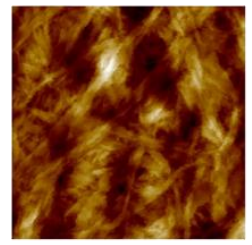

$120 \mathrm{~min}$

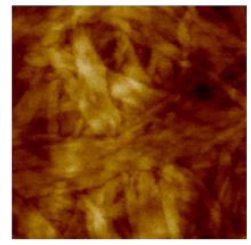

$12 \mathrm{~h}$
Figure 2: (a) Comparison of the evolution of the $-\Delta f_{1}$ (full curve) and dissipation (dashed curve), measured by QCM-D, as function of time when $0.90 \mathrm{mM}$ Fmoc-FFY $\left(\mathrm{PO}_{4}{ }^{2-}\right)$ solution is brought in contact with the multilayers PEI(PSS/PAH) 2 -ALP-(PAH/PAA-CFF-Fmoc) (red), PEI-(PSS/PAH) 2-ALP (blue) and (PEI-(PSS/PAH) 2 -ALP-(PAH/PAA-CGGG-Fmoc) (black); (b) Typical AFM images $\left(1 \times 1 \mu \mathrm{m}^{2}\right)$, obtained in contact mode and dry state, of gel obtained after $5 \mathrm{~min}(z$-scale $=76 \mathrm{~nm}), 120 \mathrm{~min}(z$-scale $=40 \mathrm{~nm})$ and $12 \mathrm{~h}(z$-scale = $15 \mathrm{~nm})$ of contact with Fmoc-FFY $\left(\mathrm{PO}_{4}{ }^{2-}\right)$ solution.

For this purpose, we built the multilayer architecture PEI(PSS/PAH) 2 -ALP-(PAH/PAA-CFF-Fmoc), represented in Figure 1a and followed its buildup by QCM (Figure S3). The calculated thickness of this film is about $53 \mathrm{~nm}$ according to Sauerbrey's relation. ${ }^{[15]}$ When this film was brought in contact with $0.90 \mathrm{mM}$ of $\mathrm{Fmoc}-\mathrm{FFY}\left(\mathrm{PO}_{4}^{2-}\right)$ solution, an increase of $-\Delta f_{1}$ and $D_{1}$ occurred within 10 min after the injection of Fmoc-FFY $\left(\mathrm{PO}_{4}{ }^{2-}\right)$ and reached respectively $1400 \mathrm{~Hz}$ and $1200 \times 10^{-6}$ after $12 \mathrm{~h}$ (Figure 2a). This indicates the buildup of a gel at the interface. These values are even larger than those observed when ALP was in solution (Figure $\mathrm{S} 1$ in $\mathrm{SI}$ ). When a Fmoc-FFY $\left(\mathrm{PO}_{4}{ }^{2-}\right)$ solution $(0.90 \mathrm{mM})$ was brought in contact with a film containing ALP and ending by PAA-CGGG-Fmoc, only a small increase of $\Delta f_{1}(10 \mathrm{~Hz})$ and of $D_{1}\left(135 \times 10^{-6}\right)$ took place (Figure 2a). We verified, using paranitrophenol phosphate as chromogenic enzyme substrate, that when PAA-CFF-Fmoc is replaced by PAA-CGGG-Fmoc the enzymatic activity of the film does not 
change (Figure S4). In order to get an idea about the synergy between the presence of the enzyme layer and the seed-layer we performed also an experiment with the multilayer PEI$(\mathrm{PSS} / \mathrm{PAH})_{2}-\mathrm{ALP}$ ending with a bare enzyme layer. When bringing this film in contact with a Fmoc- $\mathrm{FFY}\left(\mathrm{PO}_{4}{ }^{2-}\right)$ solution at 1 $\mathrm{mg} / \mathrm{mL}$ one observes an increase of $-\Delta f_{1}$ of $271 \mathrm{~Hz}$. This shows that a "bare" enzyme layer allows getting a gel at the interface as first shown by Ulijn et $a^{[8]}$ yet with a lesser efficacy. But the major drawback of the bare enzyme layer is the absence of possibility to tune and control the activity of this layer.

The gel buildup with a PAA-CFF-Fmoc seed-layer was also followed by Fourier transform infrared spectroscopy in attenuated total reflection mode in deuterated water. After the injection of $\mathrm{Fmoc}-\mathrm{FFY}\left(\mathrm{PO}_{4}{ }^{2-}\right)$, the intensities of the vibration bands at $1630 \mathrm{~cm}^{-1}$ and $1688 \mathrm{~cm}^{-1}$ increase and then level off after $60 \mathrm{~min}$ (Figure $\mathrm{S} 5$ in $\mathrm{SI}$ ). The band at $1630 \mathrm{~cm}^{-1}$ correspond to the carbonyl groups of the amide I involved in $\beta$ sheet assemblies ${ }^{[16]}{ }^{[17]}$ and the band at $1688 \mathrm{~cm}^{-1}$ can be assigned to carbamates present in the antiparallel $\beta$-sheets composed of Fmoc-FFY self-assembly [18]. A fluorescence spectroscopy study during the self-assembly of the gel shows the presence of Fmoc group excimer at $331 \mathrm{~nm}$, in accordance with the $\beta$-sheet assembly characteristic of peptide-based hydrogel (Figure S6 in SI). ${ }^{[17]]}$ Using Atomic Force Microscopy (AFM) in dry state, we imaged the obtained gel after 2, 4, 20, 120 min and $12 \mathrm{~h}$ of contact of Fmoc-FFY $\left(\mathrm{PO}_{4}{ }^{2-}\right)$ solution with PEI-(PSS/PAH) 2 -ALP-(PAH/PAA-CFF-Fmoc) film (Figure $2 b$ and Figure S7). After 4 and $20 \mathrm{~min}$, nanofibers appear over the whole coated substrate with entanglements and local bundles. After $120 \mathrm{~min}$ and $12 \mathrm{~h}$, the nanofibrous structure appears as growing flat ribbons with a diameter of about $100 \mathrm{~nm}$. Less than $4 \mathrm{~min}$ are necessary to the surface nucleation process to form fibers and the internal architecture of the gel changes overtime despite the fact that the QCM signals level off after 20 min.

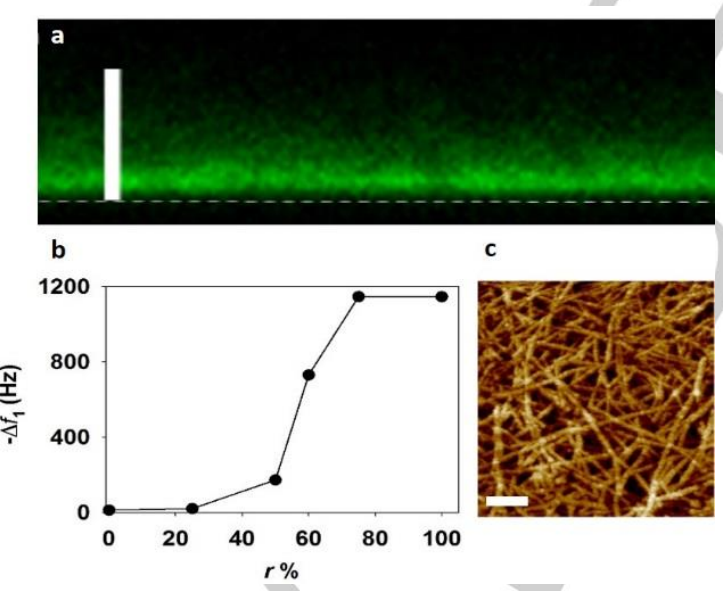

Figure 3: (a) Confocal microscopy cross-section image of the gel selfassembled from Fmoc-FFY $\left(\mathrm{PO}_{4}{ }^{2-}\right)$ on PAA-CFF-Fmoc seed-layer ended film in the presence of BSA ${ }^{\mathrm{FITC}}$. The dashed line represents the substrate and the scale bar represents $5 \mu \mathrm{m}$. (b) Evolution of $-\Delta f_{1}$ measured by QCM-D after 12 $h$ of contact of PEl-(PSS/PAH) $)_{2}$-ALP-(PAH/(PAA-CFF-Fmoc; PAA-CGGGFmoc with Fmoc-FFY $\left(\mathrm{PO}_{4}{ }^{2-}\right)$ solution, as a function of the mass ratio $r=$ [PAACFF-Fmoc]/([PAA-CGGG-Fmoc]+[PAA-CFF-Fmoc]) in the buildup solution. (c) Typical AFM image $\left(1 \times 1 \mu \mathrm{m}^{2}\right)$ obtained in contact mode and dry state after 12 $\mathrm{h}$ of self-assembly of gel from Fmoc-FFY $\left(\mathrm{PO}_{4}{ }^{2-}\right)$ on multilayer ended with a ratio $r=0.75$. The $\mathrm{z}$ scale is $34 \mathrm{~nm}$ and the scale bar represent $0.15 \mu \mathrm{m}$.

Confocal microscopy was used to determine the thickness of the gel after 12 h. PEI-(PSS/PAH) 2 -ALP-(PAH/PAA-CFF-Fmoc) was spin-coated step-by-step on a glass substrate and then brought in contact for $12 \mathrm{~h}$ with a mixture of $\mathrm{Fmoc}-\mathrm{FFY}\left(\mathrm{PO}_{4}{ }^{2-}\right)$ and fluorescein-labeled albumin (BSA $\left.{ }^{\mathrm{FITC}}\right)$. BSA ${ }^{\mathrm{FITC}}$ was used for visualization purposes to be trapped in the gel during its growth. A gradient of fluorescence extending over several micrometers appears from the surface, suggesting a gradient of BSA ${ }^{\text {FITC }}$ and thus also of fiber density extending from the multilayer to the solution (Figure 3a).

Next, we looked at whether the concept of active seed-layer allows precisely controlling the film buildup by modifying the density of "Fmoc-FF" peptide moieties on the surface. This was done by adsorbing the seed layer from a solution containing a mixture of PAA-CFF-Fmoc and PAA-CGGG-Fmoc. Thus, the multilayer film PEI-(PSS/PAH) $)_{2}$-ALP-(PAH/(PAA-CFF-Fmoc; PAA-CGGG-Fmoc)) was prepared with various mass ratios equal to $r=0,0.25,0.50,0.60,0.75$ and 1.0 with $r=$ [PAA-CFFFmoc $] /([P A A-C G G G-F m o c]+[P A A-C F F-F m o c])$. The value of $\Delta f_{1}$ measured after $12 \mathrm{~h}$ for each ratio $r$ is given in Figure $3 \mathrm{~b}$. By decreasing the proportion of PAA-CFF-Fmoc in the buildup solution of the seed-layer, $-\Delta f_{1}$ corresponding to the gel buildup decreases correlatively. With $r$ values below 1 after $12 \mathrm{~h}$, the resulting gels show a less dense network of fibers, without formation of large ribbons (Figure 3c). In addition, by decreasing the density of ALP in the multilayer, one observes correlatively a quasi linear decrease of the gel buildup kinetics when the film is brought in contact with the initiating Fmoc- $\mathrm{FFY}\left(\mathrm{PO}_{4}{ }^{2-}\right)$ solution peptide (Part 3 in SI).

To sum up, we have introduced the concept of bioactive seed-layer that triggers the buildup of a self-assembling peptide fiber network exclusively at the film/solution interface. Furthermore, by using confinement of enzymes through multilayer film design, the self-assembly process is maintained continuously and autonomously "alive" without any intervention of external stimuli. These two features render our concept fully original. In addition, the use of a bioactive seed-layer allows controlling and tuning both the network kinetics and the fiber morphologies. Currently, the research carried out in the field of self-assembly systems focuses on the development of increasingly complex architectures organized onto a surface, going closer to systems developed by nature. We believe that our bottom-up approach can significantly contribute to the design of sophisticated and smart nanoarchitecture systems.

Keywords: surface $\cdot$ self-assembly $\bullet$ thin layers $\cdot$ hydrogels seed layer

[1] G. Rydzek, L. Jierry, A. Parat, J. S. Thomann, J.-C. Voegel, B. Senger, J. Hemmerlé, A. Ponche, B. Frisch, P. Schaaf, F. Boulmedais, Angewandte Chemie International Edition 2011, 50, 4374-4377.

[2] C. Maity, W. E. Hendriksen, J. H. van Esch, R. Eelkema, Angewandte Chemie International Edition 2015, 54, 998-1001.

[3] a) X.-W. Shi, C.-Y. Tsao, X. Yang, Y. Liu, P. Dykstra, G. W. Rubloff, R. Ghodssi, W. E. Bentley, G. F. Payne, Advanced Functional Materials 2009, 19, 2074-2080; b) E. K. Johnson, D. J. Adams, P. J. Cameron, Journal of the American Chemical Society 2010, 132, 5130-5136.

[4] Z. M. Yang, H. W. Gu, D. G. Fu, P. Gao, J. K. Lam, B. Xu, Advanced Materials 2004, 16, 1440-1444.

[5] Y. Kuang, J. Shi, J. Li, D. Yuan, K. A. Alberti, Q. Xu, B. Xu, Angewandte Chemie International Edition 2014, 53, 8104-8107.

[6] J. Li, Y. Gao, Y. Kuang, J. Shi, X. Du, J. Zhou, H. Wang, Z. Yang, B. Xu, Journal of the American Chemical Society 2013, 135, 9907-9914.

[7] Q. Wang, Z. Yang, Y. Gao, W. Ge, L. Wang, B. Xu, Soft Matter 2008, 4, 550-553.

[8] R. J. Williams, A. M. Smith, R. Collins, N. Hodson, A. K. Das, R. V. Ulijn, Nature Nanotechnology 2009, 4, 19-24.

[9] a) Z. Y. Tang, Y. Wang, P. Podsiadlo, N. A. Kotov, Advanced Materials 2006, 18, 3203-3224; b) K. Ariga, T. Mori, J. P. Hill, Chemical Science 2011, 2, 195-203. 
[10] a) G. Decher, Science 1997, 277, 1232-1237; b) J. Borges, J. F Mano,

Chem Rev 2014, 114, 8883-8942.

[11] K. Ariga, Y. Yamauchi, G. Rydzek, Q. M. Ji, Y. Yonamine, K. C. W. Wu, J.

P. Hill, Chem Lett 2014, 43, 36-68.

[12] Y. Lvov, K. Ariga, I. Ichinose, T. Kunitake, Journal of the American

Chemical Society 1995, 117, 6117-6123.

[13] N. Javid, S. Roy, M. Zelzer, Z. Yang, J. Sefcik, R. V. Ulijn,

Biomacromolecules 2013, 14, 4368-4376.

[14] W. J. M. FrederixPim, G. G. Scott, Y. M. Abul-Haija, D. Kalafatovic, C. G.

Pappas, N. Javid, N. T. Hunt, R. V. Ulijn, T. Tuttle, Nat Chem 2015, 7, 30-37.
[15] G. Sauerbrey, Z Phys. 1959, 155, 206-222

[16] J. Kong, S. Yu, Acta Biochimica et Biophysica Sinica 2007, 39, 549-559.

[17] A. M. Smith, R. J. Williams, C. Tang, P. Coppo, R. F. Collins, M. L. Turner, A. Saiani, R. V. Ulijn, Advanced Materials 2008, 20, 37-41.

[18] a) S. Fleming, P. W. J. M. Frederix, I. Ramos Sasselli, N. T. Hunt, R. V.

Ulijn, T. Tuttle, Langmuir 2013, 29, 9510-9515; b) N. Yamada, K. Ariga, M.

Naito, K. Matsubara, E. Koyama, Journal of the American Chemical Society 1998, 120, 12192-12199.

\section{Entry for the Table of Contents}

\section{COMMUNICATION}

The growth of peptide based-hydrogel initiated exclusively from surface can be realized and controlled by using a bioactive seed-layer. Based on multilayer film design, this functionalized thin film allows the selfassembly to occur in close vicinity of the surface through seeding peptide. Confined into the seed-layer, an enzyme ensures the gradient production of self-assembling peptides from the surface in a continuous and autonomous way.

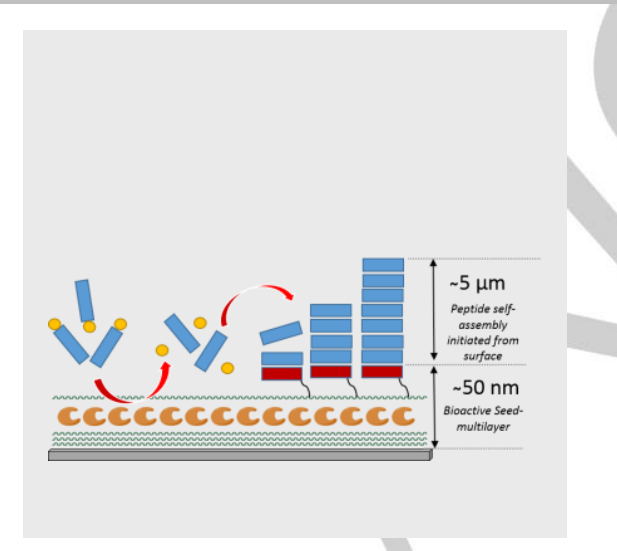

Cécile Vigier-Carrière, Tony Garnier, Déborah Wagner, Philippe Lavalle, Morgane Rabineau, Joseph Hemmerlé, Bernard Senger, Pierre Schaaf*, Fouzia Boulmedais* and Loïc Jierry

Page No. - Page No.

Bioactive Seed Layer for surface confined self-assembly of peptides 